\title{
How is the coup impacting science and scientists in Sudan?
}

\author{
Ahmed A. H. Siddig ${ }^{1,2, *}$ and Aaron M. Ellison ${ }^{3,4}$ \\ ${ }^{1}$ Faculty of Forestry, University of Khartoum, Khartoum North, Postal Code 13314, Sudan \\ ${ }^{2}$ Department of Environmental Conservation, University of Massachusetts, 160 Holdsworth way, \\ Amherst, MA 01003, USA \\ ${ }^{3}$ Sound Solutions for Sustainable Science, Boston, Massachusetts, 02135 USA \\ ${ }^{4}$ Harvard Forest, Harvard University, Petersham, Massachusetts 01366 USA
}

\section{Author contributions}

Ahmed Siddiq wrote this essay

Aaron Ellison edited this essay

*Corresponding author: Ahmed Siddig (ahmed_nyala@yahoo.com) 
Military coups (MCs) continue to occur in developing countries with alarming frequency; the current coup in Sudan being the most recent. Regardless of the arguments and rationales behind coups, there is a wide global consensus that coups pose devastating threats to the countries' development and surrounding regions.

Sudan is notable for its longstanding unrest; the current political instability is the latest in a continual period dating to the 1950s. The 2019 revolution and political agreement eased this instability and provided a new paradigm of governance and a path toward a transition to sustainable democracy based on the "constitutional declaration". Unfortunately, on October $25^{\text {th }}$ 2021, the military leader of the country again took power through an aggressive coup against the government's civilian partners, throwing away the dreams of forty million people of Sudan for a transition to, and building of, a civil and democratic state. After the coup, the military leadership immediately put in place many repressive measures in place, cancelation of the transitional constitution, a declaration of state of emergency, detaining the prime minister and some of his cabinet, arresting many activists, restricting mobility, locking down the bridges in the capital Khartoum, and stopping communications and internet service. Despite these repressive practices, the coup leaders announced and have continued to declare that this new regime is only interested in ensuring a safe and transparent transition of power to a civilian government.

Despite the already bad economic situation of the country_-inflation is running over $400 \%$ - these repressive measures have shocked and devastated all Sudanese people, Scientists are especially hard-hit and threatened by this situation. In this short essay, we report our own view on the impacts and consequences of this military crackdown and its measures on scientists of Sudan, and conclude with some thoughts for the future. A particular emphasis is on the 
impacts of the ongoing internet blockade on Sudanese students and researchers, and its long-term and large-scale effects on their ability to build successful academic careers.

First and foremost, there is no doubt that access to interment services is a human right and a pre-requisite for successful education and scientific research processes. The need for internet access is even more acute during the COVID-19 pandemic lockdown, because research and education has come to depend on virtual modes of communication.

From personal observations and discussions with many colleagues and students— despite the difficulty of communications due to intermittent telephone service and restricted mobilityon impacts of the coup on academic life, I have learned that there are thousands of students who have been completely without internet service and have not been able to access the literature, finalize papers and other writing assignments, access data repositories and statistical analysis tools, attend regular online-classes, sit for online exams, participate in meetings and seminars, or apply for many scholarships.

Many Sudanese scientists and environmental activists were not able to attend, much less follow online, the COP26, the United Nation's Climate Change Conference held in Glasgow, Scotland in late October and early November 2021. Other researchers have, for example, missed deadlines for applying for research grants, responding to reviewers' comments and submitting revised manuscripts, completing reviews for international journals, registering for upcoming meetings and conferences, or attending job interviews.

Further, many Sudanese students and researchers who are currently studying or working abroad are suffering emotionally because of disconnections from their families and friends whom 
they used to be able to contact through social media applications. Financial transactions between friends and family members in Sudan and abroad are further limited because of the internet blockade imposed by the military government.

International responses to this coup have included strong condemnation, suspension of Sudan's membership in some regional and international forums, freezing of funds and assistances, threats to re-impose economic sanction, and undoing cancellation of debts. Unfortunately, all these measures also will have serious long-term impacts on research and education in the country comparable to those experienced during the 30-year dictatorship (19892019) of Omar Al-Bashir. These included the blocking of access to much-needed education and research technology and the removal of Sudan from the list of countries eligible for many academic scholarships and research grants.

Finally, scientists and researchers are intellectual leaders in politically fragile countries like Sudan. We must engage in nationwide civil initiatives as part of our commitments to community development within the network of Sudanese (and universities in other East African countries) to raise awareness and teach our students and colleagues the principles of building peaceful and civil societies, community consolidation, rational governance, anticorruption and transparency, norms of peaceful transfers of elected power, and sustainable democracy. We also need to join political parties and stand for election to parliament and other legislative bodies within the governmental system. The rationale for these actions is straightforward. A large portion of the Sudanese population is not educated and has been co-opted by the military, armed groups, militias, repressive political parties, and tribal leaders. Thus, scientists and other intellectuals have a critical role to play in mitigating future coups through formation of a robust 
civil society and comprehensive campaigns to raise awareness. Right now I call on the major technology companies-Microsoft, Apple, Google, Meta, Twitter, etc. - to develop ways to allow "offline" access to the internet for nations of developing countries. Such access should be especially targeted at students and researchers in support of equity in education and research, and to stand with those individuals and groups working for freedom of speech and to end the control of authoritarian regimes in Sudan and throughout the world.

19 January 2022 